\title{
Relacje interpersonalne w odsłonie życia codziennego społeczności domu pomocy społecznej
}

Życie codzienne od wielu już lat zajmuje niekwestionowanie ważne miejsce w badaniach naukowców z różnych dziedzin, takich jak choćby: historyków, filozofów, socjologów czy antropologów. Eksploracją codzienności zajmują się też etnografowie, zagłębiając się w tajniki codziennego życia typowego dla rozmaitych społeczności czy instytucji. Wskazują oni, że jedną z cech codzienności jest jej dynamiczny charakter, gdyż ulega ona zmianie tak często, jak często zmieniają się konteksty i aspekty ludzkiego życia. Zależność tę ukazują wyraźnie zaprezentowane przez autorkę badania własne, w których skupiono się na odsłonięciu jednego z najważniejszych aspektów codzienności, jakim są wzajemne relacje, łączące członków społeczności Domu Pomocy Społecznej. Jak się okazuje, mimo licznych reform, którymi od lat 90. XX wieku objęto zasady funkcjonowania tego typu placówek, chcąc zmienić je z popularnego dotąd wzorca instytucji totalnej na coraz częściej upowszechniany wzorzec instytucji demokratycznej, w nie wszystkich DPS-ach udało się tego dokonać w takim samym stopniu. Wyniki badania dają podstawę do refleksji, iż działalność DPS-ów wymaga wielu jeszcze przeobrażeń i stanowi ogromne wyzwanie na najbliższe lata.

Słowa kluczowe: dom pomocy społecznej, codzienność, relacje interpersonalne, personel, podopieczni

\section{Interpersonal relations in the context of daily life of a nursing home}

For many years everyday life has been unquestionably important in the research of scientists from various fields, such as historians, philosophers, sociologists and anthropologists. Ethnographers also deal with the exploration of everyday life, delving into the secrets of everyday life typical of various communities or institutions. They point out that one of the characteristics of everyday life is its dynamic character, because it changes as often as the contexts and aspects of human life. This dependence is clearly shown by the authors' own research, which focused on uncovering one of the most important aspects of everyday life, which are the mutual relations that connect members of a nursing home community. As it turns out, despite numerous reforms, which have covered the principles of functioning of this type of institutions from the 1990s, wanting to change them from the popular pattern of the total institution to the increasingly popular model of the democratic institution, not in all nursing homes it was possible to do so in equal measure. The results of the study provide the basis for reflection that the activity of nursing homes requires many more transformations and is a huge challenge for the coming years.

Keywords: social welfare home, daily, relationship, staff, proteges 


\section{Codzienność Domu Pomocy Społecznej jako przestrzeń naukowych dociekań - wprowadzenie}

Codzienność to pojęcie powszechnie nam wszystkim znane. Choć trudno ją zdefiniować, to bez trudu przyjdzie nam się zgodzić, że otacza ona ludzi jak powietrze, swym zasięgiem obejmując wszystkie sfery naszego życia, różne konteksty i przestrzenie, w których się ono toczy. Z powodu swej wielowymiarowości, codzienność od stuleci jest przedmiotem naukowych dociekań różnych dziedzin. Etnometodologowie zajmują się eksplorowaniem zwyczajnych codziennych praktyk, ustalających porządek społeczny, do których zaliczyć można m.in.: interpersonalne relacje, komunikację, ludzkie zachowania i nawyki (Nowicka 2010: 117-118). Teoretycy wychowania, interesując się codziennością opisują to, w jaki sposób przebiega koegzystencja pedagoga i wychowanka w tak zwanej codzienności wychowania (Walczak, 2016: 84-94). Odkrywaniem tajników i opisem życia codziennego zajmują się również teoretycy i badacze z dziedziny historii, antropologii kulturowej czy socjologii. Badaniom poddaje się zarówno ludzkie wytwory materialne i werbalne (ustne i pisemne), którym nadawane są odpowiednie znaczenia i wartości, i które umożliwiają zachowanie oraz utrwalenie choćby skrawka wciąż przemijającej codzienności. Przedmiotem badań są również ludzkie świadome i nieświadome wybory, kultura, mentalność, sposoby zaspokajania ludzkich potrzeb, jak i różne konteksty, w których toczy się życie codzienne. Każdy bowiem kontekst i należąca do niego przestrzeń cechuje się własnym rodzajem codziennej rzeczywistości, w której jednostka odgrywa określone role.

Przedstawiciele socjologii życia codziennego (tak zwanej „trzeciej socjologii”) podkreślają, że z naszych codziennych zachowań wyrasta właściwie wszystko społeczeństwo, instytucje, cechy, które się przypisuje systemowi, czyli podstawowy, jak się zwykło uważać, przedmiot socjologii (por. Sztompka 2009). Przykłady różnorodnej eksploracji badawczej można odnieść do pracy, gospodarki, konsumpcji, religii (Łukasik, 2013: 36-37), rodziny, w tym również wiążących się z nią ról społecznych i obowiązków (Łukasik 2013: 66-72), rekreacji i rozrywki (Łaciak 2009: 277-296). Znane są również próby rozpoznawania codzienności w odniesieniu do życia w szpitalach psychiatrycznych i innych instytucjach określanych jako totalne (Goffman 2011).

Najważniejszym aspektem codzienności we wszystkich kontekstach, są interakcje międzyludzkie. Rozumienia i przeżywania codzienności innych uczymy się w trakcie socjalizacji, w czym niezwykle pomocna okazuje się być również komunikacja. Język ułatwia nam bowiem tworzenie międzyludzkich interakcji, interpretację różnych sytuacji społecznych oraz jest podstawą do nadawania znaczeń i produkowania intersubiektywnej, uniwersalnej wiedzy o świecie. Choć czasem 
wydaje się nam, że przez życie idziemy samotnie okazuje się, że od narodzin aż do śmierci żyjemy w otoczeniu innych ludzi, działamy według ustalonych przez nich regut, przejawiamy wobec ludzi różne postawy, uczucia i zachowania. Podczas obcowania z innymi dzielimy się z nimi społecznie konstruowaną, wspólną dla wszystkich wiedzą na temat codzienności, co ułatwia nam jej zrozumienie (Łukasik 2013: 36; Sztompka 2009: 32-33).

Życie codzienne $\mathrm{w}$ różnego rodzaju instytucjach jest szczególnie interesującym poznawczo obszarem. Jednymi z takich instytucji są Domy Pomocy Społecznej. Jak pisze Zbyrad (2014: 7), są to instytucje o dość skomplikowanej i długiej historii, gdyż ich dzieje sięgają czasów średniowiecza. Motywem do tworzenia tego typu placówek było i jest zresztą do dziś, społeczne zapotrzebowanie. Na przełomie wieków, DPS-y przechodziły przez różne etapy rozwoju: od przytułków, poprzez zakłady specjalne i domy opieki, aż po obecnie znane domy pomocy społecznej; od funkcjonowania placówek na zasadach instytucji totalnej (zamkniętej), po stopniowe przeobrażanie się i działanie zgodnie z wzorcem instytucji demokratycznej (otwartej), od uprzedmiotawiania mieszkańców, ku coraz częstszemu traktowaniu ich w sposób podmiotowy. Przez wiele lat funkcjonowanie DPS-ów wpisywało się we wzorzec opisywanych przez Goffmana instytucji totalnych, w których toczące się życie codzienne cechowało się ściśle określonymi ramami i podlegało jednolitej, zwierzchniej władzy, narzucającej swym podwładnym zuniformizowany sposób wykonywania codziennych praktyk, co wiązało się z całkowitym brakiem indywidualizacji (Goffman 2011: 16). Życie w tego typu instytucjach cechowało się kumulacją wszystkich czynności i praktyk codziennych oraz zaspokajaniem potrzeb ludzkich $\mathrm{w}$ jednym miejscu, jak również wspólną koegzystencją dwóch grup - personelu i mieszkańców, które postrzegały siebie nawzajem $\mathrm{w}$ sposób $\mathrm{z}$ reguły nieprzychylny i stereotypowy, a łączące ich stosunki opierały się na podporządkowaniu i zależności podopiecznych od kadry (Goffman 2011: 16).

Wymuszenie zmian w obszarze funkcjonowania DPS-ów wiązało się w Polsce między innymi z pewnymi społecznymi procesami, wśród których można wymienić: integrację, demokratyzację czy deinstytucjonalizację, które weszły w życie od lat 90. XX wieku, kiedy to reformie ulegał cały ustrój państwa (Zbyrad 2014: 7-10). Obecnie, DPS-y są formalnymi organizacjami o charakterze pomocowym, świadczącymi na rzecz beneficjentów usługi w głównej mierze opiekuńcze, bytowe i wspomagające, określone na mocy odpowiednich przepisów prawnych, na przykład Ustawa z dnia 8 lutego 2018 r. o zmianie ustawy o pomocy społecznej (Dz. U. z 2018 r., poz. 700) czy Rozporządzenie Ministra Rodziny, Pracy i Polityki Społecznej z dnia 17 stycznia 2018 roku zmieniające rozporządzenie w sprawie domów pomocy społecznej (Dz. U. z 2018 r., poz. 278). Instytucje te sprawują pieczę nad osobami, które przez brak zdolności do samodzielnego funkcjonowania 
w społecznym życiu wymagają pomocy innych, a które nie otrzymują tego wsparcia ze strony rodziny. Celem DPS-ów jest zapewnienie podopiecznym stałego lub okresowego pobytu, gwarancja całodobowej opieki oraz, zgodnie ze standardem świadczonych usług, zaspokajanie potrzeb bytowych, społecznych, religijnych i edukacyjnych (Zbyrad 2014: 8-9).

Codzienne życie mieszkańców DPS-ów, to życie uwikłane we wzajemne relacje z personelem i innymi mieszkańcami. Przez 30 ostatnich lat, czyli od chwili rozpoczęcia reform w obszarze działalności DPS-ów, przeprowadzono sporo badań, których wyniki pozwalają ujrzeć zróżnicowany charakter tych stosunków. Jak w swych badaniach wykazali Tarkowska (1994: 67-68), Kraus (2007: 14-17), Niedbalski (2013: 56), relacje łączące kadrę i podopiecznych mogą przyjmować formę asymetryczną, co uwidacznia się przez zależność mieszkańców wobec personelu, ich przedmiotowe traktowanie, wyręczanie przez opiekunów oraz infantylizację podopiecznych, przejawiającą się w języku kadry oraz w odgórnie narzuconym sposobie i czasie zaspokajania potrzeb mieszkańców. Przyczyną widocznej w tych relacjach asymetrii jest ciągły brak czasu, poświęcany z reguły tylko na pospieszne zaspokajanie elementarnych potrzeb mieszkańców (Gielas 2005: 27), frustracja kadry z powodu znikomych efektów osiąganych $w$ terapii podopiecz- nych (Kraus 2007: 18) oraz niskie zarobki, niewspółmierne z kosztami psychicznymi ponoszonymi podczas pracy (Zbyrad 2014: 194). Wszystko to prowadzi więc do wypalenia zawodowego, a to z kolei do mechanicznego wykonywania swych obowiązków. Niektóre badania prowadzą do bardziej optymistycznych konkluzji. Jak bowiem wykazali: Mielczarek (2006: 28-88), Machulska (2010: 264-275) oraz wyniki raportu sporządzonego przez Regionalny Ośrodek Polityki Społecznej w Białymstoku (2013/2014: 51-52, 66), większość mieszkańców uważa łączące ich z pracownikami relacje za zadowalające i znacznie poprawiające jakość ich życia, za sprawą takich aspektów, jak: zaspokajanie przez personel potrzeb wyższych mieszkańców, niesiona przez kadrę pomoc czy szanowanie prawa podopiecznych do samodzielnego dokonywania wyborów.

Mimo tego, że obecnie panujące w DPS-ach standardy uległy wyraźnym zmianom i odbiegają od tych tradycyjnych, znanych z lat wcześniejszych, to jednak nadal ciążą nad nimi tradycje z przeszłości co z kolei sprawia, że przebywanie $\mathrm{w}$ tego typu instytucjach odciska swoje piętno na ludzkiej biografii. Blokada przed pójściem z duchem czasu leży przede wszystkim w obyczajowości, a nie $\mathrm{w}$ standardach zawartych $\mathrm{w}$ przepisach prawnych. Reform można oczekiwać w głównej mierze, gdy nastąpi gruntowna zmiana zachowań i postaw ludzkich. Jeśli o codzienności mówią rzeczy w działaniu, a nie rzeczy w katalogach, spisach i taksonomiach, uwaga badawcza winna być skierowana nie tyle na jawne wzory kultury instytucji, formułowane explicite, lecz na wzory ukryte, które możemy identyfikować poprzez analizę i interpretację zachowań uczestników życia. Kul- 
tura ukryta to rytuały, przekonania, wartości, a w końcu wzorce zachowań i sposoby myślenia ludzi nienazywane wprost, niepromowane - często sprzeczne z wartościami deklarowanymi oficjalnie. Próba zrozumienia kultury instytucji zarówno w jej wymiarze jawnym, jak i ukrytym jest prawdziwym wyzwaniem dla każdego szefa firmy (Krzywosz-Rynkiewicz 2004: 45-55).

\section{Koncepcja badań własnych}

Przedmiotem badań własnych uczyniono życie codzienne w DPS-ie, z ukierunkowaniem uwagi na interakcje międzyludzkie, a więc na relacje panujące między personelem a podopiecznymi, wzajemne kontakty pracowników (kadry medycznej, terapeutów zajęciowych i fizjoterapeutów), wzajemne relacje mieszkańców. Zamysłem autorki było ukazanie ich jakości w odniesieniu do różnego rodzaju praktyk i sytuacji życia codziennego mieszkańców ${ }^{1}$. W kontekście ustalonego w placówce dziennego planu, poddano analizie sposób, w jaki członkowie kadry zaspokajają elementarne potrzeby swych podopiecznych, jak na przykład te dotyczące zabiegów higienicznych, fizjologii, odżywiania się czy potrzebę komfortu fizycznego. Dodatkowo, analizie poddano wymiar przestrzenny, w którym dochodzi do zaspokajania pragnień mieszkańców oraz formy aktywności podejmowane przez nich zarówno podczas zajęć, jak i w czasie wolnym.

Do odkrywania tajników życia codziennego społeczności DPS-u wybrano badania etnograficzne, umożliwiające dogłębną obserwację i zrozumienie stylu życia, zachowań i codziennych praktyk w badanej instytucji (Angrosino 2010: 24; Borowska-Beszta 2005: 39-40). Autorka podejmując się realizacji zadania badawczego była zarazem wolontariuszką w badanej placówce, dlatego też, zgodnie z wymogami badań etnograficznych, jej obecność w życiu społeczności była długotrwała i osobista, co dało możliwość zgromadzenia dużej ilości materiału, dzięki czemu łatwiej było opisać eksploatowaną rzeczywistość w jej faktycznym kontekście (por. Angrosino 2010: 45; Gibbs 2011: 256).

Dla zachowania holistycznego charakteru badań etnograficznych oraz dla uzyskania obszernej ilości danych, zastosowano jeden ze sposobów triangulacji, polegający na jednoczesnym łączeniu ze sobą kilku technik badawczych, z czego główną z nich była obserwacja uczestnicząca. Oznacza to, iż autorka w sposób bezpośredni uczestniczyła w codziennym życiu badanych, przypatrując się i analizując ich społeczne normy, obyczaje i wzajemne interakcje w naturalnym dla

1 Przedstawione w niniejszym opracowaniu ustalenia wykorzystują badania własne realizowane $\mathrm{w}$ ramach pracy magisterskiej napisanej pod kierunkiem dr hab. Sławomiry Sadowskiej, prof. UG na temat Codzienność w domu pomocy społecznej - badania etnograficzne, IP UG, Gdańsk 2019. 
nich kontekście. Dodatkowo, badaczka wchodziła z członkami grupy w różnego typu relacje i mówiła ich językiem, na własnej skórze doświadczając odczuć, jakie w różnych chwilach przeżywali respondenci. Kwestie te silnie podkreśla się w literaturze $\mathrm{w}$ odniesieniu do realizacji takiego podejścia badawczego (Flick 2011: 139; Gibbs 2011, 259). To, że autorka nie ujawniła swojej pozycji badacza, pozwoliło na ujrzenie codzienności w zupełnie innym świetle. Do badań wykorzystano również naturalne, spontaniczne rozmowy z respondentami, w których pytano ich o opinie na temat łączących ich wzajemnych relacji. Należy jednak zaznaczyć, iż nigdy nie były to typowe wywiady, gdyż autorce zależało na tajności badań. Drogą gromadzenia materiału empirycznego stały się dla badaczki prowadzone przez nią w sposób spontaniczny notatki terenowe, co - jak zauważa Gibbs (2011: 62) - jest typowe dla raportów z badań etnograficznych. Za pomocą notatek autorka relacjonowała wszelkie sytuacje, których była świadkiem, opisywała zasady panujące $\mathrm{w}$ placówce, codzienne praktyki, a w oparciu o nie wzajemne stosunki członków grupy oraz towarzyszące im zachowania i emocje. Dużą część notatek stanowiła strona werbalna interakcji. Składało się na nią mnóstwo cytatów i fragmentów rozmów prowadzonych w różnych sytuacjach. Dzięki analizie języka łatwiej było określić jakość relacji łączących respondentów.

Terenem badań był DPS w województwie pomorskim. Placówka ta działa w sferze publicznej, oferując beneficjentom świadczenia medyczne i całodobową opiekę. W placówce przebywa około 26 podopiecznych, choć ich liczebność ulega ciągłej zmianie. Są to seniorzy z niepełnosprawnością fizyczną i intelektualną (demencją lub zespołami otępiennymi), osoby po przebytym udarze mózgu lub cierpiące na chorobę Alzheimera, Parkinsona czy choroby przewlekłe. Personel DPS-u stanowi 10 pielęgniarek, 5 opiekunów medycznych, 2 terapeutki zajęciowe, 3 salowe i 2 fizjoterapeutki. W skład społeczności DPS-u wchodzi również grupa 20 wolontariuszy, zarówno młodzieży, jak i osób w średnim wieku urozmaicających mieszkańcom czas dzięki rozmowie lub wspólnemu graniu w gry planszowe.

Badania trwały ponad półtora roku. Zgromadzony w tym czasie materiał empiryczny, stanowił dobre źródło do opisu wzajemnych relacji łączących członków badanej społeczności. Analiza zebranych danych jest również podstawą do wyciągnięcia wniosków i refleksji na temat funkcjonowania polskich DPS-ów w XXI wieku.

\section{Analiza wyników badań}

Rzeczą wartą podkreślenia na wstępie jest to, że pracowników i mieszkańców DPS-u dotyka powtarzalny rytm codziennej rzeczywistości. Reguły funkcjonowania placówki uzależnione są od narzuconego odgórnie planu. O 7.00 pobudka 
i ubieranie przez personel osób biorących udział w terapii zajęciowej. Godzinę później, mieszkańcy ci spożywają na świetlicy wspólne śniadanie, potem otrzymują kawę i deser. O godzinie 10.00 rozpoczyna się terapia zajęciowa, trwająca do południa. Między godziną 12.00 a 13.00 jest obiad, po którym mieszkańcy udają się na fizjoterapię lub spędzają czas wraz z wolontariuszami. Godzina 14.00 obwieszcza koniec zajęć, a pielęgniarki rozwożą seniorów do sal i kładą do łóżek, w których spożywają oni podawaną o 17.00 kolację, i w których spędzają czas do następnego rana. Nakaz leżenia $w$ łóżkach obowiązuje mieszkańców również $\mathrm{w}$ dni wolne od zajęć. Wtedy to upływający czas przepełniony jest nudą i monotonią, spędzany na biernym oglądaniu telewizji, czytaniu lub w większości przypadków, na bezczynnym leżeniu i czekaniu na kolejny posiłek, zmianę pieluchy lub czyjeś odwiedziny. Na taki sposób spędzania godzin popołudniowych i weekendów narzekają niemal wszyscy, najczęściej zaś osoby bardziej sprawne, dla których dni wolne są udręką. Podczas gdy my cieszymy się z nadchodzącego weekendu, ludzie ci mówią:

Pan J. (senior): „Dla mnie, to jest, wie pani, nielogiczne. Chore zasady tu jakieś maja. No, żeby cztowiek prawie trzy dni w tóżku leżat?! I jeszcze na sali nie ma z kim porozmawiać, bo panowie jacyśs nieskorzy do rozmowy sa".

Pani T. (seniorka): „Wie pani co? Ja to się nie chcę jeszcze kłaść do tóżka. Ja to bym jeszcze $z$ wami pogadata i poszydetkowata. A nas, to rozbiora, wie pani... W koszule, jednego po drugim ubiora i idq te siostry".

W trakcie jednej z rozmów postanowiłam zapytać terapeutkę o to, jaki jest powód obowiązkowego leżenia w łóżkach w dni wolne. Zastanawiało mnie to, dlaczego nikt (personel) nie reaguje na tę sytuację. Moja rozmówczyni odpowiedziała mi wtedy:

Terapeutka [wyjaśnia badaczce]: „Tak już po prostu jest. W taki sposób placówka funkcjonuje od zawsze i nikt tego nie zmieni. Jeśli mnie nie ma w pracy, bo jest weekend, sa święta albo mam urlop, to pacjenci wtaśnie w taki sposób spędzają czas, czego ja sama pojać nie jestem w stanie".

Większa część kadry wydaje się nie mieć nic przeciwko panującym w placówce zasadom. Personel medyczny podchodzi do nich z dużą obojętnością. Zależy im na tym, aby jak najszybciej uporać się z przebraniem podopiecznych i z położeniem ich. Często słyszałam wyjaśnienia:

Pielęgniarka: „To mi ma być dobrze. Uporam się z ich przebraniem i z głowy. Niech leża”.

Pielęgniarka: „Ja nie mam zamiaru się narobić. Pięć lat do emerytury mi zostało, to po co mam się zaharowywac".

Powtarzalny rytm dnia dopełnia powtarzalność codziennych posiłków. Na śniadanie i kolację serwuje się codziennie albo zupę mleczną albo kanapki 
z szynką. Równie ubogi i powtarzalny jest jadłospis obiadowy: kurczak, ryż z jabłkami, a co piątek znienawidzona przez mieszkańców ryba. Mimo, iż badani rzadko narzekają na jakość serwowanych posiłków, to jednak z ich ust padają stwierdzenia, że w domu to były obiady, a tu są tylko zjadliwe. Od domowych, posiłki różnią się również tym, że spożywa się je tylko za pomocą łyżek, często w zupełnej ciszy. Codzienną kolację oraz wszystkie posiłki podczas weekendów konsumuje się w pokojach, siedząc przy nocnej szafce albo leżąc w lóżkach, co bardziej przypomina warunki szpitalne, niż domowe. W tym kontekście można zauważyć, że mieszkańcom odbiera się możliwość naturalnych dla ludzi doświadczeń społecznych. Odnosząc się do opisywanych tu zasad można powiedzieć, że pracownicy realizują swoją pracę $\mathrm{w}$ sposób rutynowy a monotonia wykonywanych obowiązków prowadzi ich do zobojętnienia na potrzeby mieszkańców, co prowadzi z kolei do ich przedmiotowego traktowania. Zapis z notatki terenowej wyraźnie ilustruje tę kwestię:

Pora posiłku. Salowa czeka kilkanaście minut na to, by sprzątnąć talerze mieszkańców. Gdy jedna z mieszkanek zwleka z dokończeniem obiadu, cierpliwość salowej się kończy.

Salowa [staje przy mieszkance i mówi]: „Słonko! Ty jedz, bo ja dłużej czekać nie będę. Najadłaś się kochanie? To dziękuję".

Mówiąc to zabiera posiłek mieszkance, czemu ta nie zaprzecza.

Mieszkańcy zazwyczaj nie upominają się głośno o realizację potrzeb w odmienny sposób. Może jest tak dlatego, że wyrażanie przez nich zdania nie prowadzi do prób rozwiązania problemu przez personel? W sytuacji wyrażenia chęci zjedzenia czegoś innego, jedna z mieszkanek w odpowiedzi od salowej usłyszała:

Salowa [do mieszkanki] „A co ty byś księżniczko na śniadanko chciała? Kawior może, co?”.

Inna z mieszkanek opisała następująco swoją próbę rozmowy w tej kwestii z personelem:

Pani H. (seniorka) [wyjaśnia badaczce]: „Jak kiedyś spytałam siostrę (pielęgniarkę) czy nie ma może marmolady do chleba, bo na kiełbasę już patrzeć nie mogę, to mi odpowiedziata, że marmolady nie dostanę a kiełbasę trzeba jeść, bo zdrowa. A jak nie chcę kiełbasy, to nie muszę jeść wcale. I więcej już o nic nie poprositam".

Indywidualnych preferencji mieszkańców nie bierze się również pod uwagę personel pielęgniarski, a każda prośba o ponadprogramowe zaspokojenie potrzeb, wiąże się z niezadowoleniem kadry. Ma to miejsce między innymi w przypadku zaspokajania potrzeb fizjologicznych, które każe się wielu mieszkańcom załatwiać w pieluchę, a nie w toalecie. Często można usłyszeć zdania, wypowiadane przez kadrę bezosobowym, oschłym tonem:

Pielęgniarka [do jednej z mieszkanek]: „A po co robić na toaletę, jak jest pampers! Do pampersa trzeba robić! My nie będziemy latać co chwilę z góry, bo ktośchce do toalety! My mamy dość pracy"! 
Pielęgniarka [do innego mieszkańca]: „O nie! Ja jej sama nie będę targać do toalety, a potem z powrotem na świetlicę! Ona jest za ciężka! Nawet we dwie nie damy rady! Albo idzie na górę $i$ się załatwia, a potem leży, albo niech siedzi i robi w pampersa! Przecież go ma"!

W tej instytucji dobry czas na czynności fizjologiczne to czas, który wyznacza personel. Kadra zdaje się nie zważać na to, że dla seniorów, zwłaszcza tych w pełni władz umysłowych, dyskomfortem jest załatwianie tych potrzeb w pampersa, a potem siedzenie lub leżenie w nim przez resztę dnia, gdyż przewijanie odbywa się dwa, góra trzy razy dziennie. Złość pielęgniarek wynika z tego, że w przebranie podopiecznego lub w pomoc w skorzystaniu z toalety muszą włożyć więcej wysiłku i czasu, niekiedy angażując w tę czynność drugiego pracownika. Dlatego też personel stara się tego uniknąć i woli przebrać wszystkich w tym samym czasie, nakazując seniorom załatwiać się do pieluch.

Z uprzedmiotowieniem spotykamy się też w przypadku minimalnego zakresu zaspokajania potrzeb związanych z osobistą higieną. Rzadkie zmienianie pieluch, golenie wszystkich mężczyzn tą samą maszynką, kąpiel co dwa tygodnie są jednymi z odgórnie narzuconych zasad i żadnemu z pracowników nie przyjdzie na myśl, aby przeciw nim zaoponować mimo, że przez brak higieny mieszkańcy narażeni są na wiele chorób skórnych. Oni sami, do warunków panujących w DPS-ie przystosowują się w sposób bierny, tylko czasami skarżąc się na swój los:

Pani J. (mieszkanka) [do wolontariuszki (badaczki)]: „Pani sobie wyobraża, że my tu jesteśmy kąani co dwa tygodnie? Ja ciagle czuję, że mam tak bardzo klejące ręce. I w ogóle cata się kleję. Nie mogę tego znieść".

Z dużą obojętnością kadra medyczna podchodzi również do czynności, które są znaczące dla poczucia komfortu seniorów, wiążącego się z brakiem cierpienia fizycznego. Czynności te realizuje w istocie tylko wtedy, gdy nakazuje to plan. Często zdarza się, że z sal dobiega krzyk mieszkańców, proszących o wcześniejsze położenie do łóżka, gdyż nie mają siły na dłuższy udział w zajęciach lub jęczących z bólu i proszących o uśmierzający go lek. Szczególnym przykładem takich sytuacji jest reakcja pielęgniarek na prośby personelu terapeutycznego o uśmierzenie bólu jednej z mieszkanek uczestniczącej w zajęciach świetlicowych:

1.02.2019. Pani J. siedzi na świetlicy i cierpi z powodu silnego bólu brzucha. Personel medyczny nakazuje jednak kobiecie zostać na świetlicy, ponieważ na podanie kroplówki nie nadszedł jeszcze czas. Bóle nasilają się. Pani J. jęczy coraz głośniej, twarz ma bladą, jej ciałem wstrząsają drgawki. Jakby tego było mało okazuje się, że kobieta ma pełną pieluchę.

Zirytowana terapeutka mówi do wolontariuszki (badaczki): „To jest nienormalne! Dzwoniłam już parę razy, ale nikt nie przychodzi! Oni nie sa wcale zajęci, bo siedzą na dyżurce i gadaja, a J. mi się tu męczy". 
Gdy kolejny dzwonek nie daje rezultatu, terapeutka postanawia sama pójść na górę i sprowadzić pielęgniarkę. Po chwili wraca zrezygnowana, mówiąc: „Nawet mi nie powiedzieli, że ktoś przyjdzie. Jak staratam się im tłumaczyć, że J. boli i chyba ma brudna pieluchę, powiedzieli tylko: Ona tak ma".

Pani J. została na świetlicy do końca zajęć, a cierpienie z jej twarzy nie zniknęło.

Często w podobnych sytuacjach pracownicy wypowiadają obojętne zdania typu:

Pielęgniarka [do wolontariuszki (badaczki)]: „To jest histeryczka. Ona tak ma”;

Pielęgniarka [do wolontariuszki (badaczki)]: „Pani im tak we wszystko nie wierzy, bo oni tylko chca na siebie uwagę zwrócić".

Słaba jakość opieki, jaką personel medyczny i salowe otaczają mieszkańców, jest powodem konfliktów z terapeutkami. Terapeutki mają za złe reszcie kadry to, że swoje obowiązki wykonują w sposób opieszały, niedokładny i bez jakiejkolwiek empatii. Stawiają wymagania, ażeby stan tej opieki poprawić. W rozmowach prowadzonych z terapeutkami często można było usłyszeć:

Terapeutka 1 [do wolontariuszki (badaczki)]: „Ostatnio, jak po raz kolejny zwrócitam pielęgniarkom uwagę, żeby wzięty pacjentów z brudnymi pieluchami ze świetlicy, to o mało mnie nie zlinczowaty. Skupity się w parę i do mnie z ryjem: «Jesteś taka mądra?! Gonisz nas do roboty, to sama stawaj z nami i dupy im myj!». Dziś też: przychodzę do roboty i styszę podśmiechujki na mój temat, ale ja przestatam już zwracać na nie uwagę. Tak czy inaczej uważam, że stosują wobec mnie mobbing";

Terapeutka 2 [do wolontariuszki (badaczki)]: „Czasem mam wrażenie, że ja mam chyba schizofrenię, bo oni (kadra) traktują mnie, jak dwie różne osoby. Rano, jak przychodzę na górę i pomagam pacjentom ubrać się, żeby mogli iść na zajęcia, to normalnie ze mna gadaja, żartuja i w ogóle. Ale jak jestem na świetlicy i proszę ich, żeby wzięli pacjenta na górę, bo coś się dzieje, to jak grochem o ścianę. Albo wcale nie przychodza, albo przychodza, ale ja mam potem do stuchania".

Z kolei kadra medyczna, zarzuca terapeutkom nadgorliwość i zmuszanie ich do wykonywania dodatkowych jak sądzą zadań, które tak naprawdę należą do ich obowiązków. Spory pracowników kończą się z reguły wezwaniem terapeutek na rozmowę z dyrekcją i reprymendą z powodu braku umiejętności pracy w grupie, przy czym żadnych tłumaczeń kobiet nie bierze się pod uwagę. Podczas takiej właśnie rozmowy, jednej z terapeutek oświadczono, że zostaje ona zwolniona z pracy, za powód podając brak chęci i umiejętności współpracy zespołowej. Personel wieść o zwolnieniu koleżanki przyjął z ulgą. Nawet ostatniego dnia pracy nie szczędzono jej cierpkich słów:

Pielęgniarki [do terapeutki]: "Jak odejdziesz, to w końcu będziemy miały fajny prezent na święta. Fajnie będzie sobie rano pić kawkę i nikt nas w końcu nie będzie gonić do pracy". 
Sama terapeutka wieść o zwolnieniu przyjęła spokojnie, mówiąc o tym w sposób następujący:

„Każda wymówka jest dobra. Im się po prostu robić nie chce i każdy ma pretensje, że ja ich gonię. H. (pielęgniarka) powiedziała mi, że ma sześć lat do emerytury i nie chce się tu narobić. Na zebraniu powiedzieli mi, że jestem pierwszą osoba w tym burdelu za przeproszeniem, która chciała zmienić ten cały syf i podwyższyć poprzeczkę opieki".

Przyjrzenie się formie i zakresowi zaspokajania przez personel podstawowych potrzeb seniorów, pozwala wyciągnąć wnioski na temat jakości relacji łączących te dwie grupy. Otóż mają one wymiar asymetryczny, ukazujący dominującą pozycję kadry, co z kolei uwypukla zależność podopiecznych. W wielu przypadkach personel wykorzystuje swą nadrzędną pozycję wiedząc, że mieszkańcy nie są w stanie sprzeciwić się ani im, ani panującym w placówce regułom. Podopieczni zaś, dostosowują się do całej tej sytuacji w sposób bierny ucząc się, że należy działać na zasadach opiekunów, gdyż głos ich samych się nie liczy. Z zależnością seniorów wiąże się również ich bezosobowe, przedmiotowe traktowanie. Każda czynność związana z zaspokajaniem potrzeb podopiecznych odbywa się taśmowo i w sposób zuniformizowany. Brakuje tu miejsca na troskę o zaspokojenie ich potrzeb wyższych, jak pragnienie uznania czy szacunku.

Krzywdzącym byłoby stwierdzenie, że negatywnym, asymetrycznym wymiarem cechują się stosunki mieszkańców z całą kadrą. Z niektórymi jej członkami seniorzy nawiązują bowiem kontakty pełne troski i serdeczności. Sami seniorzy podkreślając, że zależą one od charakteru i podejścia danej osoby:

Pani J. (seniorka): „Pielęgniarki są bardzo niemite. Nie mówię, że wszystkie. Bardzo fajny jest K. O Boże! Jak ja go lubię! I pani A., taka miła i zawsze uśmiechnięta. Ale jest taka L., wredna i niemiła. Gdyby pani wiedziała, jak ona mnie dziś szarpała przy ubieraniu i jak fukała na mnie";

Pani W. (seniorka): „Nie lubię pani E. (fizjoterapeutka), bo każe mi ćwiczyć za wszelkq cenę mimo, że mnie boli. Zero empatii. Pani A. (fizjoterapeutka) to jakoś zawsze potrafi zrozumieć. Paniq A. lubię, a pani E. nie, bo fatszywa się wydaje. Tylko by gadała na wszystkich".

Relacjami, których jakość można bez wątpienia uznać za bardzo dobrą są te, łączące wszystkich podopiecznych z obiema terapeutkami. Seniorzy w sposób szczególny uwielbiali pierwszą terapeutkę, pieszczotliwie nazywaną Cyganeczką, za jej poczucie humoru, empatię i ciepło, którym ich otaczała. Gdy kobieta zmuszona była odejść z pracy, mieszkańcy ze łzami dziękowali jej za troskę, którą im okazała:

Pani Ł. (seniorka) [do terapeutki]: „Kto będzie dla nas taki dobry, jak pani?”;

Pani T. (seniorka) [do terapeutki]: „Będziemy modlić się i płakać za panią całymi dniami”. 
Równie wysoko seniorzy cenią obecną terapeutkę. Ich wzajemna relacja jest mieszanką szacunku, troski, ale i partnerstwa. Wspólne rozmowy prowadzone są otwarcie i na równym poziomie, gdzie każdy ma prawo do swobodnej wypowiedzi. Relacja ta opiera się na dużym zaufaniu seniorów do terapeutki. Jest ona jedynym pracownikiem, do którego mogą się zwrócić w każdej sprawie. Zawsze więc mówią o niej z wdzięcznością, podkreślając, że to „anioł dobroci” czy "złota kobieta”.

Niezależnie od wymiaru relacji pensjonariuszy i pracowników, wszystkie te stosunki cechuje infantylizacja, z jaką kadra traktuje podopiecznych, zwłaszcza tych o niższym poziomie funkcjonowania. Ich odnoszenie się do mieszkańców bardziej przypomina opiekę nad dziećmi niż pracę z dorosłymi. Poziom proponowanych na terapii zadań, stawianie szóstek za ich wykonanie jest jednym z tego przykładów. Jakość takiego postępowania można zrzucić na karb tak zwanego ukrytego programu, podświadomie realizowanego przez kadrę. Wśród większości pracowników tkwi przekonanie „starzy sa jak dzieci” i tak też ich traktują.

Zła jakość relacji mieszkańców z większością kadry przyczynia się również do pogłębienia się uczucia samotności, z którą boryka się wielu seniorów. Radością z powodu częstych odwiedzin rodziny poszczycić się może bowiem niewielu. Do większości z nich, goście przyjeżdżają rzadko. Czasem zjawią się wolontariusze, ale nie wszyscy umieją choć na chwilę zatrzymać się i wysłuchać tego, co senior ma do powiedzenia. Z reguły są to skargi na fizyczne dolegliwości, na brak nadziei na lepsze samopoczucie, na tęsknotę za bliskimi. Takich skarg nie chcą słuchać pracownicy, którzy zwierzenia podopiecznych przerywają zniecierpliwieni:

Salowa [do jednej z mieszkanek]: „Oj! Już niech pani tak nie narzeka! Jeść dostaje, spać gdzie ma, dzieci przyjadą. A że boli? To nic. Musi boleć, żeby kiedyś przestato".

W najgorszej sytuacji znajdują się osoby wciąż leżące, którym kadra poświęca tylko tyle czasu, ile jest konieczne na zaspokojenie potrzeb niższego rzędu. Dlatego też, ludzie ci często czują się zapomniani, niechciani. Uważają, że są balastem dla pracowników, ale przede wszystkim dla własnej rodziny. W takich przypadkach, samotność staje się nieodłączną towarzyszką w ostatnich chwilach życia seniorów, przez co ich samopoczucie psychiczne, a co za tym idzie i fizyczne, ulega pogorszeniu, co potwierdza zaprezentowana poniżej sytuacja.

11.03.2018. Pan S. (mieszkaniec) zapytał mnie dziś, na czym polega rola wolontariuszki. Mówię więc, że między innymi na poświęcaniu ludziom czasu i rozmowie z nimi.

Pan S.: "Rozmawia pani z nimi i pociesza?"

Wolontariuszka (badacz): "Kiedy trzeba, to tak".

Pan S.: "I daje pani nadzieje, której nie ma?”

Wolontariuszka (badacz): "A nie ma?"

Pan S.: „Nie. Już nie”. Mówi smutno i spokojnie. 
Wolontariuszka (badacz): "Dlaczego?"

Pan S.: "Bo wie pani... Ja się nigdy nie spodziewałem, że przyjdzie mi umierać samotnie. Bez rodziny. W takich męczarniach i bez ludzkiej godności. Ja po prostu czuję, że jestem dla kogoś kłopotem, bo nic tylko leżę i robię pod siebie. Każde z moich dzieci ma swoje obowiązki i nikt nie chce wziać do domu starego, obsrywajacego się dziadka. Ja to wie pani, już bym chciał umrzeć i nie być dla nikogo ciężarem. Najlepiej, jakby mi dali jakiś proszek na wykończenie i tyle".

W relacjach łączących pracowników i podopiecznych niezwykle rzadko dostrzec można wzajemne zaufanie czy wsparcie, tak bardzo ważne podczas życia w warunkach instytucjonalnych. Znacznie częściej, spotykamy się natomiast z obojętnością, czasem nawet z pogardą, co czyni codzienność instytucjonalną jeszcze trudniejszą. Dla wielu pracowników, pensjonariusze są po prostu jednymi z wielu. Nie myśli się o nich, jak o panu J., który woli załatwiać się na toaletę czy o pani Z., która chciałaby choć przez chwilę z kimś porozmawiać. Uprzedmiotowienie widać $w$ sposobie zwracania się kadry do mieszkańców. Typowe są zwroty bezosobowe lub zwroty $\mathrm{w}$ formie trzecio-osobowej typu:

Pielęgniarka [do jednej z mieszkanek]: „Po co wstawać z tóżka, jak kolana bola. Leżeć trzeba i w pampersa robić";

Fizjoterapeutka [do mieszkańca]: „Co by chciał? Może wody by się napit?"; "Dlaczego ćwiczyć nie chce?".

W języku personelu najrzadziej występują wulgaryzmy, jednak nie są one obce uszom mieszkańców. Słyszą oni na przykład:

Pielęgniarka [do jednego z mieszkańców]: „Nie wstawaj, bo se teb rozwalisz. Po cholerę ty wstajesz?".

Zwroty te są wyrazem nie tyle bezosobowego i obojętnego traktowania, ile wyrazem braku szacunku kadry do seniorów. Język personelu odzwierciedla sposób myślenia o seniorach jak o dzieciach. Dominującą jest forma per "ty", w której występują dziwne zdrobnienia imion, za sprawą czego pani Wiesia staje się Wiesiulą, a Wioletta - Wioletunią. Co ważne, po imieniu mogą zwracać się tylko pracownicy do mieszkańców bez względu na ich wiek, przy czym o odwrotnej sytuacji nie ma tu mowy. Dlatego częste są sytuacje, które odbiegają wzorcem od tych, jakie spotyka się w innych miejscach:

80-letni mieszkaniec [zwraca się do 30-letniej pracownicy]: „Czy mogłaby mi pani pomóc dojechać na salę"?

Pracownik: „Tak Jasieńku. Poćwiczysz trochę na rowerku, a potem pojedziemy”.

W języku pracowników nie brakuje również zdrobniałych form wyrazów i zwrotów typu:

Salowa [do jednego z mieszkańców]: „Jedzkaj ładnie żabko, to zawiozę cię na górę"; 
Terapeutka [do jednej z mieszkanek]: „Elunia, ale nie chowaj tych puzzli pod tacke, cwaniaku maty".

Tak więc, stół staje się stoliczkiem, przy którym żabki jedzą obiadek, a pani Pelasia jest mądrą dziewczynką, której terapeutka stawia szóstkę z plusem, bo ładnie pokolorowała motylka. Niekiedy, senior staje się nikim więcej, jak tylko „dziadziusiem”. Wtedy to usłyszeć możemy:

Pielęgniarka [do mieszkańca]: „Dziadek! Grzecznie mi tu leżeć! Kładziemy się do tóżeczka!”.

Innym sposobem zwracania się do seniorów jest nie występująca w zwykłych relacjach forma:

Salowa [do mieszkanki]: „Pani Basia, chcesz drugie danie?”;

Pielęgniarka [do mieszkanki]: „Pani Nowak, weź tableteczkę".

Mieszkańcy biernie przystają na sposób, w jaki personel zwraca się do nich. Z kolei jedna z terapeutek, zapytana o przyczynę używania wyżej opisanego języka wobec seniorów, odpowiedziała:

„Na początku pilnowałam się, żeby mówić pan/pani, ale potem, jak zauważyłam, że mówienie na ty im nie przeszkadza, to przestatam się tym przejmowac".

Obserwacja życia codziennego w DPS-ie uświadomiły mi, że placówka ta posiada niejako dwie twarze. Pierwsza - oficjalna, pokazywana składającym wizyty gościom, przedstawia uśmiechniętych mieszkańców, którym spędzany na świetlicy czas upływa na wspólnych śpiewach czy oglądaniu przedstawień. Seniorów otaczają równie uśmiechnięci, troskliwi pracownicy, którzy w imieniu podopiecznych wręczają gościom prezenty, rzekomo robione własnoręcznie przez seniorów, a tak naprawdę, w większości przez terapeutkę. Rzeczywistość jest jednak inna. Żadnego z odwiedzających nie zaprasza się bowiem na górę, gdzie w dusznych salach leżą ci, którzy z racji stanu zdrowia nie uczestniczą we wspólnym życiu. Oni sami nie dopominają się o niczyją uwagę, gdyż nauczeni doświadczeniem wiedzą, że rzadko kiedy ją dostaną. Leżą więc cicho, biernie czekając na to, aż ktoś przyjdzie i poda im szklankę wody, zmieni pieluchę, porozmawia.

\section{Podsumowanie}

Jak wykazała analiza wyników badań własnych, codzienna rzeczywistość panująca w DPS-ie przybiera monotonny i zrutynizowany charakter. Podejście kadry do obowiązku opieki nad pensjonariuszami można podzielić na dwie grupy - 
pracownicy, których w tej kwestii cechuje obojętność i ignorancja oraz mniejsza część kadry (w tym terapeutki), którą cechuje z jednej strony empatyczne i pełne troski działanie o zaspokajanie podstawowych i wyższych potrzeb podopiecznych, z drugiej zaś bezradność wobec panujących w DPS-ie reguł. Obie grupy łączy brak dążenia do jakichkolwiek zmian, z tym, że jedni unikają tego z powodu przyzwyczajenia się do danej sytuacji, drudzy zaś nie podejmują prób zmian wiedząc, że ani od kolegów, ani od dyrekcji nie uzyskają w tej kwestii wsparcia. Istnieje również ryzyko, że próba wyłamania się z narzuconych reguł lub ich zmodyfikowania, może wiązać się $\mathrm{z}$ utratą pracy, jak miało to miejsce $\mathrm{w}$ przypadku jednej z terapeutek, co napawa pracowników lękiem i zmusza do podporządkowania się nakazom. Taki stan rzeczy działa również na szkodę mieszkańców, od których wymaga się tylko tego, by w milczeniu dostosowywali się do narzuconych, zuniformizowanych, pełnych absurdów zasad i nakazów.

Zarówno podejście jednej, jak i drugiej grupy pracowników nie zmieni na lepsze panującej w placówce sytuacji, podobnej do działających w ubiegłym wieku goffmanowskich instytucji totalnych. Z powodu braku zmian, najbardziej cierpią najsłabsi - mieszkańcy, których preferencji nie bierze się pod uwagę, co prowadzi do ich zależności i uprzedmiotowienia oraz pozbawia ich ludzkiej godności. Postępowanie personelu wobec seniorów może po części wynikać ze zmęczenia, gdyż kadra medyczna pracuje $w$ trybie dwunasto lub dwudziestoczterogodzinnych zmian. Nie zmienia to jednak faktu, iż relacje kadry i mieszkańców muszą ulec gruntownej zmianie i nie powinny na nie wpływać trudności, związane z wykonywanym zawodem. Taki stan rzeczy działa na szkodę zarówno pracowników, prowadząc do zobojętnienia na potrzeby podopiecznych, jak również na szkodę mieszkańców, od których wymaga się tylko tego, by w milczeniu dostosowywali się do narzuconych, zuniformizowanych, pełnych absurdów zasad i nakazów.

W zakończeniu warto dodać, że bezrefleksyjne zanurzenie w kulturze instytucji i nieświadomość jej „nienaturalności”, eliminuje możliwość zmiany istniejącego status quo, bo "przecież jest dobrze". Wzory realizowane nawykowo i replikacyjnie pozostają na prymarnym poziomie zrozumiałości samej przez się („inne być nie mogą"). Zmianie status quo sprzyja wydobycie przejawów wzorów określających i organizujących codzienność DPS-u, poddanie ich refleksji. Taką funkcję mogą pełnić środowiska naukowe.

Dlatego też priorytetem jest, ażeby obszar dociekań naukowych, bardziej niż dotychczas został poszerzony o badania nad działaniem DPS-ów. Warto również przyjrzeć się temu, jak działalność tego typu instytucji odzwierciedla się w codzienności ich mieszkańców i pracowników. Należy mieć nadzieję, iż częstsza eksploracja codziennego funkcjonowania opisywanych placówek, jak również rozpowszechnienie i upublicznienie wyników badań tej problematyki, pozwoli 
na refleksyjne spojrzenie na codzienną rzeczywistość tych instytucji, a przede wszystkim egzystujących $\mathrm{w}$ nich ludzi. W rozumienie codzienności może zaangażować się bowiem każdy. Jeśli nauczymy się doświadczać i interpretować ją z perspektywy innych, stanie się ona dla nas bardziej zrozumiała, zaczniemy o niej myśleć z większą refleksją. Co równie ważne, zwielokrotnienie i większe niż do tej pory upowszechnienie wyników badań dotyczących pracy DPS-ów może przyczynić się również do wprowadzenia radykalnych reform w obrębie ich funkcjonowania. Powinny one dotyczyć głównie kształcenia i wymiany kadry. Czas bowiem najwyższy, ażeby zerwać z goffmanowskim wzorcem instytucji totalnej. W młodej generacji personelu należy zaszczepić przekonanie, iż przestał już istnieć podział na lepszych nas - opiekunów i gorszych - podopiecznych. Wszyscy jesteśmy bowiem równi, a ci, których winniśmy otaczać opieką, tak jak i my w pełni zasługują na równe traktowanie oraz życie w godnych, bliskich pozainstytucjonalnym warunkach. Dlatego też tak ważna jest powszechna wiedza na temat działalności współczesnych DPS-ów, ażeby łatwiej było przełamać związany z niecodziennym w nich życiem temat tabu i zmienić codzienność przebywających tam ludzi na bardziej naturalną, ludzką, znaną większości społeczeństwa.

\section{Bibliografia}

Angrosino M. (2010), Badania etnograficzne i obserwacyjne, Wydawnictwo Naukowe PWN SA, Warszawa.

Borowska-Beszta B. (2005), Etnografia dla terapeutów (pedagogów specjalnych) - szkice metodologiczne, Oficyna Wydawnicza „Impuls”, Kraków.

Flick U. (2011), Jakość w badaniach jakościowych, PWN, Warszawa.

Gibbs G. (2011), Analizowanie danych jakościowych, PWN, Warszawa.

Gielas J. (2005), Pobyt seniora w domu opieki catodobowej - kolejny etap normalnego życia?, „Wspólne Tematy”, nr 3.

Goffman E. (2011), Instytucje totalne. O pacjentach szpitali psychiatrycznych i mieszkańcach innych instytucji totalnych, Gdańskie Wydawnictwo Psychologiczne, Sopot.

Kraus S. (2007), Chmury nad domem pogodnej jesieni. O niedopuszczalnych sposobach postępowania z pacjentami cierpiącymi na Alzheimera, Wspólne Tematy, nr 7-8.

Krzywosz-Rynkiewicz B. (2004), Jak odkryć ukryty wymiar kultury organizacyjnej, Harvard Business Review Polska, nr 8.

Łaciak B. (2009), Przyjemności i rozrywki jako wymiar wspótczesnej polskiej codzienności [w:] Bogunia-Borowska M. (red), Barwy codzienności Analiza socjologiczna, Wydawnictwo Naukowe Scholar, Warszawa.

Łukasik J. (2013), Doświadczanie życia codziennego narracje nauczycielek na przełomie życia, Oficyna Wydawnicza „Impuls”, Kraków.

Machulska B. (2010), Powiatowe domy pomocy społecznej w opinii ich pensjonariuszy - analiza na podstawie przeprowadzonych badań empirycznych [w:] Klimek M., Czerw J. (red), 10-lecie 
funkcjonowania samorządu powiatowego (1999-2009). Doświadczenia i perspektywy, Wydawnictwo WZNoS KUL, Stalowa Wola.

Mielczarek A. (2006), Adaptacja człowieka starszego do życia w domu pomocy społecznej [w:] Kamiński T. (red), Starość. Roczniki Naukowe Caritas, Wydawnictwo Fundacja „Pro Caritate", Warszawa.

Niedbalski J. (2013), Żyć i pracować w domu pomocy społecznej. Socjologiczne studium interakcji personelu z upośledzonymi umystowo podopiecznymi, Wydawnictwo Uniwersytetu Łódzkiego, Łódź.

Nowicka M. (2010), Socjalizacja na lekcjach w klasach początkowych praktyki - przestrzenie konceptualizacje, Wydawnictwo Adam Marszałek, Torun.

Regionalny Ośrodek Polityki Społecznej w Białymstoku Obserwatorium Integracji Społecznej, (2013/2014), Opieka nad osobami niesamodzielnymi na przykładzie funkcjonowania Domów Pomocy Społecznej w województwie podlaskim, Białystok.

Rozporządzenie Ministra Rodziny, Pracy i Polityki Społecznej z dnia 17 stycznia 2018 roku zmieniające rozporządzenie w sprawie domów pomocy społecznej (Dz. U. z 2018 r., poz. 278).

Sztompka P. (2009), Przestrzeń życia codziennego [w:] Bogunia-Borowska M. (red.), Barwy codzienności Analiza socjologiczna, Wydawnictwo Naukowe Scholar, Warszawa.

Tarkowska E. we współpracy Czayki-Chełmińskiej K., Krantza W., Lisek-Michalskiej J. (1994), Życie codzienne w domach pomocy społecznej, Wydawnictwo IFiS PAN, Warszawa.

Ustawa z dnia 8 lutego 2018 r. o zmianie ustawy o pomocy społecznej (Dz. U. z 2018 r., poz. 700).

Walczak A. (2016), Etyka (w) codzienności wychowania - od nieuchronności do możliwości, Nauki o Wychowaniu. Studia Interdyscyplinarne, nr 1(2).

Zbyrad T. (2014), Od instytucji totalnej ku demokratycznej? Domy pomocy społecznej w Polsce, Wydawnictwo Naukowe UP, Kraków. 